\title{
TÜRK SINEMASI'NDA ARABESKIN DOǦUŞU VE GELişiMi
}

\begin{abstract}
Ali Murat KIRIK*
ÖZET

Sinema, dünya genelinde kitleleri etkileme gücüne sahip görsel ve işitsel bir sanattır. Bu çalışmada Türk sinemasında ortaya çıkan arabesk kültür üzerinde durulmaktadır. Arabesk kültürün oluşumunda köyden kente göç, sanayileşme ve çarpık kentleşme, gecekondulaşma gibi unsurlar yer almaktadır. Arabesk kültür, Türkiye'de yeni bir müzik türünün oluşumunu sağlamıştır. Orhan Gencebay, Ferdi Tayfur, İbrahim Tatlıses ve Müslüm Gürses gibi müzisyenler bu dönemde ön plana çıkmıştır. Orhan Gencebay ile başlayan arabesk filmler furyası Türk Sineması'nın çehresini değiştirmiştir. 1980'li yıllarda ise arabesk filmler her yaştan her kesimden izleyici tarafindan ilgiyle seyredilmiştir. 1990'lara doğru halkın kültür ve gelir düzeyinin yükselmesi ile birlikte Türk Sineması'ndaki arabesk dönem noktalanmıştır. Çalışmada literatür taraması yöntemi kullanılmış ve Türk Sineması'nın bir dönemine damgasını vuran arabesk tarihsel bir akış içerisinde irdelenmiştir.
\end{abstract}

Anahtar kelimeler: Arabesk kültür, Türk Sineması, köyden kente göç, gecekondulaşma, kentleşme

\section{BIRTH AND DEVELOPMENT OF ARABESQUE IN TURKISH CINEMA}

\begin{abstract}
Cinema which affects masses is an audio-visual art in the world. This study deals with the concept of arabesque culture, which emerged in the Turkish Cinema. Arabesque culture is formed by such as rural-urban migration, industrialization and rapid urbanization, slum housing. Arabesque culture has led to the formation of a new type of music in Turkey. Musicians like Orhan Gencebay, Ferdi Tayfur, İbrahim Tatlıses ve Müslüm Gürses has come to the fore in this period. Arabesque orgy movies which starting with Orhan Gencbay has changed the face of Turkish Cinema. In the 1980s, the arabesque films are watched by viewers of all ages from all walks. With the rise in income levels and culture of people, the period of the arabesque in Turkish Cinema has been punctuated. This study was prepared by the method of literature. In this study, arabesque which was the important period in Turkish Cinema was examined in a historical flow.
\end{abstract}

Keywords: Arabesque culture, Turkish Cinema, rural-urban migration, squattering, urbanization

\footnotetext{
* Yardımcı Doçent Doktor, Marmara Üniversitesi İletişim Fakültesi, Radyo, Televizyon ve Sinema Bölümü, murat.kirik@marmara.edu.tr
} 


\section{Giriş}

Sanayi devriminin toplum yapısında hissedilmeye başlamasıyla birlikte köyden kente göç olgusu meydana gelmiştir. Modernleşmenin ivme kazanması, kentlerde yaşamaya başlayan köylü kesimin kendi iç dinamikleriyle farklı bir yapı oluşturmalarına neden olmuştur. Böylelikle arabesk kültür meydana gelmiştir. Müzik aracılığıyla hayat bulan arabesk kültür; zamanla insanlar tarafindan bir yaşam biçimi halini almıştır (Işık ve Erol, 2002: 7-9). Türkiye'de arabesk kültürün ortaya çıkışında birçok etken saymak mümkündür. Türkiye'de arabesk; 1930'ların ortalarından başlayarak gösterime giren Mısır filmlerinde yer alan şarkıların Türkçe’ye uyarlanması ile ortaya çıkmıştır. Mısır filmleri özellikle 1936-1948 yılları arasında Türkiye genelinde yer alan köy ve kasabalarda haftalarca gösterilmiş ve bu filmler yoğun ilgiye sahne olmuştur. Adından da anlaşılacağı üzere şarkılarda hem geleneksel Arap makamları hem de doğu çalgıları kullanılmıştır (Büyük Larousse, 1986: 729). Böylelikle arabesk müzik alanında hayat bulmaya başlamıştır.

Sinema ve müzik arasında kuvvetli bir ilişki bulunmaktadır. Sinemada sesin keşfedilmesi ve müzikallerin ortaya çıkmasıyla beraber sinema ve müzik ayrılmaz bir ikili olmuşlardır (Monaco, 2006: 56). Özellikle; arabesk filmlerde senaryodan çok oyuncuların söylediği şarkılar ön plana çıkmaktadır. Arabesk, köyde de kentte de görülmeyen ve kentleşme ile birlikte oluşan yeni tür bir kent kültürü, olarak ifade edilebilmektedir. Köyde kente göç ile birlikte ailelerin yaşam tarzları değişikliğe uğramış; köydeki birincil tip dostluk ve akrabalık ilişkilerinin yerini, kentte, yazılı kurallarla düzenlenmiş ikincil tip ilişkiler almıştır. Bu soruna çözüm arayan insanlar kendine özgü değerler sistemi ve yepyeni bir kültür geliştirmişlerdir. Bununla birlikte; umudunu kaybeden insanlar "bencil" ve "benmerkezci" bir tutum benimsemişlerdir. Kırsal kültürden kopmuş ama kentlileşememiş, "bencil" ve "benmerkezci" bu yaşam biçimi, "arabesk kültür" şeklinde ifade edilmektedir (Kongar, 2004: 590). Tarih boyunca bireylerin davranış ve inançlarını yönlendiren kişiler şüphesiz ki liderler olmuştur (Güllüpunar, 2013: 30). Arabeskle uğraşan müzisyenler ise tabiri caizse o dönem için Türk toplumuna yön vermişlerdir. $\mathrm{Bu}$ isimlerin başını ise Orhan Gencebay, İbrahim Tatlıses, Ferdi Tayfur ve Müslüm Gürses gibi isimler çekmiştir. 
Literatür taraması yöntemi kullanılarak hazırlanan bu çalışmada arabesk kavramı derinlemesine irdelenerek, arabeskin tarihçesi üzerinde durulacak ve Türkiye'de arabesk kültürün oluşumunu sağlayan etmenler detaylı bir şekilde tartışılacaktır. Köyden kente göç ve kentleşmenin etkisiyle kapsama alanını genişleten arabesk müziğin sinema ile olan ilişkisi örnek filmler üzerinden açıklanarak çalışma sonlandırılacaktır.

\section{Arabeskin Kavramsal Analizi ve Tarihçesi}

Arabesk, Fransızca kökenli bir sözcük olan arabesque kelimesinden Türkçe’ye geçmiştir. Bu sözcük güzel sanatlarda “Arap usulü” anlamına gelmekte olup; "süslemede kullanılan çizilmiş veya oyma süs" ve "bazı çevre çizgilerini birleştiren, resmedilmiş veya oyma bir düzenlemenin temel ritmini meydana getiren ideal çizgi" şeklinde de ifade edilebilmektedir. Sosyal bilimlerde ise arabesk; “bozulmuş ve yozlaşmış" manasını taşımaktadır (Meydan Larousse, 1992: 47).

Eski Yunan'da, Mısır'da, İran'da, Bizans'ta değişik biçimlerde var olan arabesk, İslam sanatında daha özgün bir senteze dönüştürülmüştür. Daha sonra da bu sentez geliştirilerek İslam dünyasında oldukça önemli bir kullanım alanı oluşturmuştur. Roger Garaudy’e göre arabesk; "ritimli, hareketler halinde, filizlere bağll, ikiye ayrllan yaprak sürmelerinden meydana gelen özel şekiller ve yalnızca Íslam sanatına özgü bitki bezemesi biçimleri” olarak tanımlanabilmektedir (Güngör, 1993: 17). Arabeskin sadece müzik türü olmadığını dile getiren Belge bu sözcüğü; ev eşyası, çeşitli süsler, resimli halılar, filmlerden... vb. oluşan bir dünya, bir yaşam biçimi olarak nitelendirmektedir (Belge, 1983: 339). Türkiye’de arabesk müziğin kurucusu olarak bilinen Orhan Gencebay; arabeski “Türk sanat müziği, Türk halk müziği ve bunlara ek olarak da batı tekniğinin her türlü olanaklarına, özgür sunumun eklenmesinden oluşan bir müzik” türü olarak tanımlamaktadır (Güngör, 1993: 21). Anlaşılacağ1 üzere arabesk üzerine net bir tanımlama yapabilmek oldukça güç olmakla birlikte bu kavram birçok alanda kullanılmaktadır.

Arabesk, müzikten ziyade söz unsurunun ön plana çıkmasıyla birlikte hayat bulan bir kavram olmuştur. Duygulara seslenebilen ve kendine ait değer yargıları 
bulunan arabesk Türk sanatının farklı kollarında sıklıkla kullanılmaktadır. Arabesk üzerine önemli çalışmalar gerçekleştirmiş olan antropolog Chris Hann, bu kavramı; “duygulardan etkilenmiş düşünce” şeklinde ifade etmektedir (Birkalan, 2003: 105). Hann, duygusal bir temele sahip olan arabeskin bireylere doğrudan etki ettiğinin altını çizmektedir.

Arabesk; birbirine sarılmış ve iç içe geçmiş bitki örgeleriyle soyut eğrisel örgelerin oluşturduğu bir bezeme üslubu olarak meydana getirilmiştir. Arabesk üslup Anadolu'daki Helenistik dönem el sanatçılarının yapıtlarından türemiştir. M.S. 1000 yıllarında İslam sanatçıları tarafından arabeske biçimci bir nitelik kazandırılmıştır. Avrupa'da arabesk, Rönesans'tan 19.yüzyılın başlarına kadar özellikle el yazmalarının, duvarların, mobilyaların, metal eşyanın, çanak ve çömleğin bezenmesinde kullanılmıştır. Arabesk taş işçiliği 15.yüzyılın sonu 16.yüzyılın başlarında ortaya çıkmıştır. Kuzey İtalya ve daha sonra İspanya'da gümüş el işlerinde de arabesk öğeler kullanılmıştır. Barok üslup ortaya çıktıktan sonra arabesk bezeme üslubu ikinci plana atılmış ve eski popülaritesini yitirmiştir. Arabesk üslup 18.yüzyılın ortalarında tekrar ön plana çıkmıştır (Ana Britannica, 1996: 416-417). Görüldüğü gibi arabesk, 1900’lü y1llara kadar süsleme sanatında bir tarz olarak kullanılmakla birlikte Türkiye'de daha çok bir müzik türü olarak bilinmekte ve bu anlamına uygun bir şekilde kullanılmaktadır.

Gürbilek (2009: 25), 1970'li y1llarda var olan ve 1980'li y1llarda bir söylem nesnesi haline gelen arabesk kavramının anlam çerçevesi aşağıdaki şekilde çizmektedir:

Köyden kente göç eden bireylerin kendilerini kabul etme, seslerini duyurma ve özel bir kültür oluşturma isteği,

Büyük kentlerin yerlilerinin yabancılar akınını (köyden kente göç edenler) geri püskürtme çabalarının adı,

Aydınların ayak takımı ve taşra düşmanı elitlere yönelik kamuoyunda gerçekleştirmiş olduğu jestin adıdır. 


\section{Türkiye'de Arabesk Kültürün Oluşumu}

Türkiye'de arabesk kültürün meydana gelmesinde çeşitli sosyal etkenleri saymak mümkündür. $\mathrm{Bu}$ etkenler arasında göç olgusu, gecekondulaşma, sanayileşmeye dayalı kentleşme ve kentlileşme yer almaktadır.

\subsection{Göç Olgusu}

Göç; “insanların bir yerleşim yerinden bir başkasına ya da bir ülkeden öbürüne temelli ya da geçici bir süre için taşınması" şeklinde ifade edilmektedir. Göç eden insanlar ise "göçmen" olarak adlandırılmaktadır. Türkiye genelinde İstanbul'un en fazla göç alan il olduğu görülmektedir. Göçün ekonomik ve toplumsal boyutları bulunmaktadır. Ekonomik boyut; fiziksel çevrenin bir başka deyişle özdeksel tabanın değişmesini, toplumsal boyut da toplumsal ve kültürel çevrenin, yani manevi tabanın değişmesini ifade etmektedir. Türk toplumunda göç; "kırsal kesimden kopma ve köyden uzaklaşma" anlamına gelmektedir. 1950-1960 y1lları arasında Türkiye'deki dört büyük kentin nüfusu yüzde 75 oranında artmıştır. Böylece kentli nüfusu bu seneler içerisinde yüzde 19'dan yüzde 26'ya kadar yükselmiş, merkez ile çevrenin kültürü karşı karşıya gelmiştir. Köyden kente göç ile başlayan sosyolojik ve toplumsal değişmeler ülkenin de bütün dinamiklerinin tamamen değişmesine neden olmuştur (Güngör, 1993: 82-83).

Büyük şehirlere yaşanan göçlerin birden çok sebebi bulunmaktadır. $\mathrm{Bu}$ sebeplerin başında ekonomik koşullar gelmektedir. Kırsal kesimde yaşayan insanların daha iyi yaşam standartlarına kavuşmak istemeleri, yiyecek, içecek, barınma gibi ihtiyaçlarını karşılayabilme arzuları göç olgusunun temelinde yer almaktadır. Makineli tarıma geçilmesi ve işçilere duyulan ihtiyacın azalması da kırsal kesimi şehirlerde yaşamaya itmiştir. Sanayileşmenin yaşanmasıyla birlikte şehirlerdeki fabrika sayılarında hızlı bir artış yaşanmış, bunun üzerine iş gücü ihtiyacı doğmuştur. İşçi olmak amacıyla köyden kente göç edenlerin sayısı da çoğunluktadır. Daha iyi yaşam arzusu göç sayısının artmasına neden olmuştur (Sağlam, 2006: 35-36). Aynı zamanda büyük şehirlerin çekiciliği, ihtişamı, eğitim imkânları, kültür düzeyi, refah seviyesini yükseltebilme arzusu ve özellikle doğu illerinde karşılaşılan kan davası da göç olgusunu tetiklemiştir. 
Göçün altında yatan siyasi nedenleri de irdelemek doğru olacaktır. Politik tek seslilik, Demokrat Parti'nin ortaya çıkışıyla yok olmuştur. Cumhuriyet Halk Partisi ve Demokrat Parti arasında yaşanan siyasi çekişme halkın tercihini Demokrat Parti'den yana kullanmasıyla sona ermiştir. Demokrat Parti döneminde yeni iş sahaları oluşturulmuş ve sanayi kuruluşları hizmet vermeye başlamıştır. Yeni açılan sanayi kuruluşları işçilere ve iş gücüne ihtiyaç duymuştur. Topraksız köylüler yeni açılan sanayi kuruluşlarında çalışabilmek için köyden kente göç etmişlerdir (Işık ve Erol, 2002: 74-76). 1950-1960'lı yıllar arasında yaygınlaşan iç göç olgusu 1960'larda yerini dış göç olgusuna bırakmıştır. Kırdan kopamamış köylü kesimi daha iyi hayat koşullarında yaşayabilmek için Avrupa'daki düşük statülü ve az nitelik gerektiren işleri kabul etmişlerdir. 30 Ekim 1961 tarihinde Batı Almanya ve Türkiye arasında imzalanan Türk Alman İşçi Mübadele Antlaşması ile Almanya göçleri başlamıştır. Hatta yaşanan bu göçler Türk sinemasına da konu olmuştur. Dönüş, Otobüs, Almanya Acı Vatan gibi filmler dış göç konusunu işlemiştir. Batı Almanya başta olmak üzere Fransa, Belçika, Avusturya, İsveç gibi ülkeler de göç almaya başlamıştır. Köylerdeki ekonomik elverişsizlik, büyük kentlerdeki iş sahalarının dolması kırsal kesimde yaşayan insanları dış göçe itmiştir. İki gelenek arasında kalmış köylü kesim, göç ettiği ülkeye tam anlamıyla ayak uyduramamıştır (Esen, 2000, 121-125).

\subsection{Gecekondulaşma}

Kırsal kesimde ekilebilir alanların sınırına ulaşması, büyük kentlerin ekonomik kazanç açısından daha cazip duruma gelmesi iç göç olayını hızlandırmıştır. Böylelikle kentlerde kendine özgü yerleşim bölgeleri oluşmuştur. İç göçle birlikte gecekondulaşmaya dayalı “arabesk kültür” oluşmuştur. 1960'l1 yıllarda Türkiye'de 140 bin gece kondu bulunur iken 1980'li yıllarda bu say1 900 bine çıkmıştır (Oktay, 1987: 84-85). İstatistiklerden de anlaşılacağı üzere Türkiye'de gecekondulaşma süreci çok hızlı bir gelişim süreci içerisinde gerçekleşmiştir.

Türkiye'de gecekondulaşma hızlı kentleşmenin sonucu olarak meydana gelmiştir. Kırdan kente göç eden gelir durumu düşük olan köylü göçmenler kentlerde maddi durumlarına uygun ev bulmakta zorluk çekmişlerdir. Kentte yaşamak köylü göçmenleri ekonomik bakımdan zorlamış, böylelikle göç edenler yeni arayışlara 
yönelmiştir. Bu kişiler, iş yerlerine yakın boş arazilere kendi emekleriyle küçük evler yapmışlardır. Böylelikle gecekondulaşma had safhaya ulaşmış; kimi hükümetler ise bu kaçak yapılaşmayı oy kazanma uğruna desteklemişlerdir (Esen, 2000: 104-106).

Gecekondulaşmayla birlikte kent yapısı da değişiklik göstermiştir. Kentte yaşayan insanlar "farklılaşmış, ihtisaslaşmış, tarımsal olmayan bir iş düzeni ile işlerde çalışan gene kendi içinde farklılaşmış ve tabakalaşmış nüfus"a sahiptirler. Gecekondularda yaşayan insanlar da bu farklılaşmadan payını almışlardır. Gecekondu mahalleleri 1950'lerden başlayarak 1980'lere kadar hızlı bir şekilde oluşmaya başlamıştır. Gecekondularda yaşayan nüfus daha çok seyyar satıcılık, işportacılık, ayakkabı boyacılığı yapmaktadır (Kıray, 2007: 19). Hızlı sanayileşen ancak modernleşmeye ayak uyduramayan sanayi kentlerinde büyük nüfus hareketleri meydana gelmiş ve gecekondulaşma kendini göstermiştir. Yavaş yavaş meydana getirilen ilk gecekondu mahallelerinde kırsal yaşam tarzı ön plana çıkmıştır. Aynı köyden gelen insanların oluşturduğu gecekondu mahallelerinin tümü devlet arazisine inşa edilmiş olmakla birlikte, evlerin hiçbirinin tapusu bulunmamaktadır. Zamanla gecekondular; kırsal alanın kentteki temsilcisi durumuna gelmiştir (Işık ve Erol, 2002: 75). Fakat köyden kente göç eden köylüler geleneklerini, örflerini, adetlerini ve alışkanlıklarını bir anda terk edememişlerdir.

Gecekonduların oluşmasının birçok nedeni bulunmaktadır. Köyden kente göç eden insanlar kısa bir müddet başkalarının evlerinde kiracı olarak ikamet etmişlerdir. Ancak belli bir müddet sonra ekonomik sorunlar nedeniyle kiralarını ödeyememişlerdir. Kiralarını ödeyemeyen göçmenler gecekondulaşmayı çözüm yolu olarak bulmuşlardır. Şu bir gerçektir ki; hayat standartları ile oturulan konutun nitelikleri arasında doğrudan bir ilişski bulunmaktadır. Çağımızdaki kentleşme olgusunda da gecekondular yer almaktadır. O dönem olduğu gibi günümüzde de gecekondular alt gelir gruplarının barınaklarıdır. Kırdan kente göç eden insanlar gecekondularının yapımında masraftan tasarruf etmektedirler. Gecekondular, dost ve arkadaşların yardımı ile yapılmaktadır (Kıray, 2007: 20-23). Böylece hünerli işçi veya ustalara para ödenmemekte, aynı şekilde ekonomik bakımdan zora sokmayacak kalitesiz malzemeler tercih edilmektedir. Gecekonducular tapusuz arazilere kurulduğu için bu yapılar çoğu zaman devlet tarafından yıkılmıştır. 
Gecekondulaşma neticesinde kültür farklılıkları ortaya çıkmış ve halk öncelikle temel ihtiyaçlarını karşılama çabasına girmiştir. Gecekondular derme çatma yapılar şeklinde kurulmaya başlamıştır. Altyapısı olmayan ve fiziki açıdan elverişsiz olan bu yapılar fiziksel kirliliğe de yol açmıştır (Çalışkan, 2006: 60). Gecekondularını inşa eden göçmenler buralara geçici bir hane gözüyle bakmışlar; ancak daha sonra köye geri dönüş tamamen akıllardan çıkmıştır.

\subsection{Sanayileşmeye Dayalı Kentleşme ve Kentlileşme}

1950'li ve 1980'li yıllar arasında Türkiye'yi derinden etkileyen bir diğer toplumsal olay sanayileşmedir. Arabesk kültürün ortaya çıkışını sağlayan tüm etmenler sanayileşme süreci ile birlikte meydana gelmiş ve kentlerde hayat bulmuştur. Anlaşılacağı üzere arabesk kente ait bir kültürdür (Özbek, 2008: 26). Sanayileşmeye bağlı kapitalizmin gelişim sürecinde geleneksel üretim yapıları bozulurken, bu yapıların aktörleri olan köylü ya da küçük üretici kesim de hızlı bir değişime uğramıştır. Sermayenin büyümesine imkân verecek süreç ve değerler yayılmaya başlamıştır.

Genel bir ifadeyle kentleşme; sanayileşme ve ekonomik gelişmeye bağlı olarak meydana gelen bir süreçtir. Tarımdan sanayiye geçişle birlikte kentler giderek büyüme göstermiştir. Anormal biçimde meydana gelen büyüme insan davranışlarının ve kültürel etkinliklerin değişmesine neden olmuş, işbirliği ve örgütlenme yerini uzmanlaşmaya bırakmıştır. Kentleşme, sanayi devriminin ürünü olarak yorumlanmaktadır. 18.yüzyıla geçiş ile birlikte gerek dünyada, gerekse de Türkiye'de geleneksel yaşam giderek çehresini değiştirmiştir (Bağl1, 2004: 31). Türkiye'de kentleşme ve kentlileşmenin eş zamanlı olmayışı bu iki kavramın farklı bir şekilde gelişmesine yol açmıştır. Çünkü kentleşme sürecini kentlileşme takip etmiştir.

Kıray; kentleşmenin, toplumdaki yapısal değişimin temelini oluşturduğunu ifade etmektedir. Çünkü kentleşme; nüfusun büyük oranının tarımdan ve topraktan kopup tarım dışı alanlarda, sanayide, karmaşık örgütlerde ve dolayısı ile köyden başka yerlerde, kentlerde hayatlarını kazanmaya ve yaşamaya başlamaları olarak tanımlanmaktadır. Toplum yapısı içinde gelişen bu tip değişmeler insan ilişkilerinin 
de yeniden düzenlenmesini gerekli kılmaktadır. Gelişmiş ülkelerde toplumsal değişmelerin etkisi daha az yaşanırken; Türkiye gibi gelişmekte olan ülkeler ve az gelişmiş ülkelerde bu değişiklikler daha etkili bir biçimde hissedilmektedir. Nitekim Türkiye'de kentleşme olgusu ile birlikte toplumun temel dinamikleri tamamen değişmiştir. Kentin ana nüfusunu uzmanlaşmış işçiler oluşturmaktadır. Sanayileşme hamlesi ile birlikte fabrikada çalışan işçilerin hepsinin bir uzmanlık sahası olmuş, uzmanlaşma ile birlikte işsizlik sorunu meydana gelmiştir (Kıray, 2007: 141-143). Gelişmekte olan sanayi toplumlarında kentle bütünleşmeden söz edebilmek oldukça güçtür. $\mathrm{Bu}$ toplumlar yeni sanayi hamleleri içerisinde bulundukları için toplum yapıları bir o kadar karmaşıktır. Kırdan kente göç eden insanlar bu karmaşık yapının ayrılmaz parçalarıdır.

Türkiye'de göç ve kentleşme kavramı birbirleriyle eş zamanlı bir şekilde gelişim göstermiştir. Çünkü göç olgusu ile birlikte kentleşme kavramı meydana gelmiştir. Keleş, kentleşmeyi; sanayileşmenin etkisiyle bireylerin köyden kente göç ederek buralarda yaşamış oldukları uzmanlaşma, iş bölümü ve örgütlenme sonucu toplumsal ilişkilerini oluşturduğu bir nüfus birikim süreci olarak nitelendirmektedir (Sağlam, 2006: 36-37). Avrupa'nın büyük şehirlerinde de kentleşme süreci yaşanmış, ancak bu süreç çok daha düzenli bir şekilde gerçekleştirilmiştir. Fakat Türkiye'de meydana gelen kentleşme ve kentlileşme süreci çok düzensiz bir şekilde yürütülmüş, devletin bu sürecin herhangi bir safhasına doğrudan müdahalesi olmamıştır.

Gecekondu sakinlerinin fabrikalarda, çeşitli iş sahalarında çalışmaya başlamasıyla birlikte gelir durumları yükselmiştir. Daimi işlerde çalışmaya başlayan göçmenler küçük olan gecekondularını genişletmişlerdir. Yaşam biçimlerini yavaş yavaş değiştiren göçmenler toplumsal statülerini de yükseltmek istemişlerdir. Kentlere alışmaya başlayan insanlar popüler kültür ürünlerini tüketmeye başlamışlardır. Özenti sonucunda ucuz fabrikasyon mobilya, borç harç alınmış televizyonlar, radyolar, buzdolapları, müzik teypleri, plastik çiçekler, tabaklar ile gecekondu evlerini donatmışlardır (Oktay, 1987: 85). Kentlileşmeye özenen gecekondu kesimi zenginleşemeyince yoksul olduğunun farkına varmıştır. Yoksul olduğunu anlayan halk içinde yaşadığı topluma yabancı hale getirmiştir. 
Yabancılaşma, arabesk kültürün doğmasına ve gelişim göstermesine neden olmuştur. Dolayısıyla arabesk; yabancılaşmanın meydana getirdiği bir kültürdür.

\section{Arabesk Müzik ve Sinema iliş̧kisi}

Arabesk müzik çok farklı şekillerde tanımlanabilmektedir. Ancak unutulmamalıdır ki arabesk bir müzik türü olmaktan ziyade başlı başına kültürdür. Türkiye'de arabesk, bir müzik türü olarak ön plana çıkmış ve Türk Sineması'nın bir dönemine damga vurmuştur. Tam bu noktada arabeski bir müzik türü olarak tanımlamak yerinde olacaktır.

\subsection{Bir Müzik Türü Olarak Arabesk}

Türk müziğine eserleriyle katkı sunan Timur Selçuk arabeski; “Türk sanat müziği ve Türk halk müziğinden etkilenen, batı tarzı yapay motif ve tavırlar da katarak çağdaş bir müzikal, azgelişmişlik örneği olarak ülkemizin ekonomik ve kültürel tablosunu büyük bir ustalıkla sergileyen ritmik yapıslyla dinamizmden uzak, tekdüze bir müzik.” şeklinde ifade etmektedir. Araştırmacı Engin Ergönültaş’a göre arabesk; "kentleşmeyle ortaya çıkan değerler karmaşasının bütün yansımalarını içeren, halk müziğinden, klasik Türk müziğine, doğulu dinsel seslerden batının en gelişmiş elektronik müzik aletleriyle elde edilebilen karmaşık seslerden oluşan ve minibüs müziği olarak adlandırllan müziktir" (Güngör, 1993: 22).

Arabesk müziğin kurucusu olarak bilinen Orhan Gencebay; arabesk müzik kavramına itiraz etmektedir. Ona göre arabesk kelimesi "Arapvari”, "Arap etkinliği " anlamına gelmekte olup yapmış olduğu müzik tarzını nitelememektedir (Coşkun, 2001: 27). Gencebay, arabesk müzik kavramının basın tarafından ortaya atıldığına vurgu yapmakta ve Türk müziğinden bağımsız çalıştığını ifade etmektedir.

Adorno'ya göre müzik, çağdaş toplumun ikilemlerini ve çelişkilerini bünyesinde barındırmaktadır (Oskay, 1995: 69). Adorno'nun ifade ettiği gibi çağdaş toplumun ikilem ve çelişkileri arabesk müzikte kendini göstermektedir. Arabesk müzik, acının ve yoksulluğun bir ifadesidir. Acı ve yoksulluk ise toplumsal yapının çelişkileridir. Aristoteles'in da belirttiği gibi müzik aracılığıyla "kahtarsis" sağlamaktadır. Böylece insanlar dertlerinden, sorunlarından kısa bir zaman dilimi için de olsa kurtulabilmektedirler. Özellikle arabesk müzik katharsis eşliğinde 
yabancılaşmaya da hizmet etmektedir. Çünkü arabesk müzik dinleyen bireyler yaşanan dünyayla ilişiklerini kesmektedirler. Adorno'ya göre yabancılaşma toplumsal değişimin hızlı yaşandığı ülkelerde gerçekleşmektedir (Oskay, 1995: 31). Türkiye'de de 1950-1970'li yıllarda toplumsal değişim hızlı bir şekilde yaşandığı için yabancılaşma olgusu kendini göstermiştir. Yabancılaşma; insanın kendi çevresiyle, toplumuyla ve dünyasıyla çelişmesidir.

\subsection{Arabesk Müzik ve Popüler Kültür İlişkisi}

Arabesk müzik ve popüler kültür ilişkisine değinmeden önce popüler kültürün kavramsal olarak ne ifade ettiğinin bilinmesi gerekmektedir. Popüler kültür; orta sınıfa ait bir kültür olup; halkın kültürü, değer yargıları, davranışları ve eğlence biçimlerinin bütünüdür. Popüler kültürün ürünleri nüfusun büyük bir çoğunluğuna seslenebilmektedir. Seçkin bir kitleye yönelik olmayan ve genel olarak kitle iletişim araçlarıyla iletilen yaşam öğeleridir (Alemdar ve Erdoğan, 1994: 151). Dolayısıyla popüler kültürün öğelerinin tümü belli bir kitleye yönelik sunulmamaktadır.

Popüler kültür ve popüler kültürün ürünleriyle gündelik hayatta pek çok kez karşılaşılmaktadır. Özellikle Türkiye'de popüler kültürün etkileri gayet açıktır. Bu açıdan belirli bir kesim tarafından popüler kültür; gündelik yaşamın kültürü olarak da düşünülmektedir. Popüler kültür aracılığıyla yeni yaşam tarzları üretilmekte ve çeşitli ideolojiler yaygınlaştırılmaktadır. Popüler kültür ürünleri çoğu zaman aldatıcı bir niteliğe sahiptir. $\mathrm{Bu}$ açıdan bireyleri çoğu zaman etkisi altına alabilmektedir (Batmaz, 1981: 163). Arabesk filmlerde de bu aldatıcılı̆̆ görmek mümkündür. Arabesk filmlerde seyircilere sürekli olarak hayali bir dünya sunulmaktadır. Bireyler gerçek aşkın olabileceğini düşünmekte ve zengin-fakir aşkına olumlu gözle bakmaktadırlar. Çünkü popüler kültür sürekli olarak umudu canlı tutmaktadır. Dünyayı ve var olan gerçekliği değiştirme arzusu popüler kültür içerisinde sürekli bulunmaktadır.

Kırdan kente göç eden kesim, geleneklerini, göreneklerini, alışkanlıklarını da beraberinde getirmiş ve şehir standartlarına bir anda alışamamıştır. Bu açıdan göç ettiği dönem içerisinde köylü-kentli ikileminde kalmıştır. Kentli olmaya özenen ve toplum tarafindan kabullenmek istenen birey için taklit en temel yöntem olmuştur. 
Kentli gibi tüketmek bir çıkış noktası olarak düşünülmüştür. Ancak, ekonomik koşulların elverişsizliği ve yetersiz imkânlar nedeniyle kırdan kente göç eden birey maddi gücü dâhilinde harcamalarını gerçekleştirmiştir. Topluma adapte olamayan birey büyük bir gerilim içerisine girmiş ve kendisini ifade edemeyeceğini düşünmüştür (Ang1, 2013: 64). Hayatta pek fazla çıkar yolu kalmayan, sürekli sorunlarla mücadele eden bireyin tek kurtuluş yolu arabesk müzik olmuştur. Böylece arabesk müzik kendine özgü bir kültür oluşturmuştur.

Arabesk kültürün ortaya çıkmasıyla birlikte müzik anlayışı da değişikliğe uğramıştır. Özellikle 1960’lı yılların sonunda Orhan Gencebay ile birlikte gelişim gösteren arabesk müzik, Türkiye'nin o dönemki şartları göz önüne alındığında karamsarlık, umutsuzluk, mutsuzluk ve acı gibi öğeleri yansıttı̆̆ı için Türk halk1 tarafından büyük rağbet görmüştür. Birkaç yıl içerisinde Gencebay’ın yarattığı bu tarz özellikle kırdan kente göç eden gecekondulu gençlerin yoğun ilgisini çekmiştir. Orhan Gencebay; yaptığı müzikle kendinden sonra gelen arabeskçilere de örnek olmuştur. Kısa bir süre sonra bu türde müzik yapan yeni besteci ve şarkıcılar çıkmıştır. Bu isimler arasında başta İbrahim Tatlıses olmak üzere, Ferdi Tayfur ve Müslüm Gürses'i saymak mümkündür. Zamanla arabesk müzik, popüler kültürün vazgeçilmezi haline gelmiştir. Böylece arabesk müzik bünyesinde yer bulan çeşitli enstrümanlar pop müzikte de kullanılmaya başlamıştır. 1980'lerin ortalarında Türk Sineması ile kapsama alanını genişleten arabesk müzik kolayca tanımlanamayan, sınırları belirlenemeyen ve devamlı zenginleşen bir müzik türü haline gelmiştir.

1950-1960’lı y1llarda başlayan toplumsal hareketler ve göç olgusu arabesk müziğin gelişimini desteklemiştir. Böylece ortak bir kültür oluşmaya başlamış ve arabesk kültür popüler bir boyut kazanmıştır. Ancak arabesk müziğin homojen bir yapıda olmadığını söylemek mümkündür. Çünkü arabesk Türkiye genelinde yer alan folklorik öğelerin bileşkesinden oluşmaktadır. Arabesk müzik farklı beklentileri, umitleri, korkuları ve isyanları aktaran bir müzik türü olarak toplumun karşısına çıkmıştır. Aynı zamanda arabesk müzik halkın beklentileri ve beğenilerine göre kendisini şekillendirmeye çalışan bir tür olmuştur. Arabesk fakir halkın sığınağı ve umudu konumuna gelmiştir. Bu nedenle arabeskçilere "baba" sıfatı atfedilmişstir. 
"Orhan Baba", "Ferdi Baba", "Müslüm Baba" gibi isimler toplumun büyük beğenisini kazanmış ve aidiyet duygusu benimsenmiştir (Güngör, 1993: 91).

Arabesk müziğin tüketici kitleleri zamanla genişlemiş ve arabesk hem kırsal hem de kentsel alanda sevilen bir müzik türü haline gelmiştir. Arabeskin birçok toplumsal sınıf arasında yaygınlaşmasının temel nedeni popüler kültürdür. 19681979 yılları arasında özellikle gecekondularda başkaldırı olarak görülen arabeske TRT hiçbir şekilde yer vermemiştir. Bu yüzden arabesk Türk halkına çekici gelmiştir. Arabeski ticari bir meta olarak düşünen yapımcılar hemen bu alana yatırım yapmış, böylece arabeske dayalı bir müzik endüstrisi ortaya çıkmıştır. Arabesk türüne yönelen müzisyenlerin kasetleri, plakları... vb. popüler kültürün öğeleri olmuştur (Özbek, 2008: 119-120). Bu öğeler hemen tüketilebilen, halkın geniş bir kesimi tarafından anlaşılan ve rağbet gören şarkılar olmuştur. Popüler kültürün devreye girmesiyle birlikte arabesk müzik Türk halkı tarafından beğenilen bir duruma gelmiştir.

Sosyolojik bir olgu olarak gelişim gösteren arabesk müziğin var oluş sebebini sadece gecekondulaşma ve hızlı kentleşme gibi nedenlere bağlamak pek doğru değildir. Göçün arabesk kültürün oluşumunda önemi yadsınamaz derecede büyük olsa da Orta Doğu ve özellikle Mısır kökenli müzik anlayışı Türk toplumunu derinden etkilemiştir. Cumhuriyet döneminden itibaren radyoda doğu müziklerine yer verilmesi Türk Müziğì'nin çehresinin değişmesine neden olmuş ve daha çok Anadolu'da varlığını sürdüren arabesk müzik giderek büyük kentlere ve metropollere yayılmıştır. Dönmez'in (2011: 236-237) de belirttiği gibi arabesk müzik ekonomik sorunları, kötü hayat koşullarını, sefaleti, yabancılaşmayı, şehre ait olamamayı, acıları, yoklukları ve aşkı bünyesinde barındırmaktadır.

Kent yaşamında istediklerini bir türlü bulamayan, iyi koşullar altında yaşamayan, işsizlik sorunuyla karşı karşıya kalan ve sürekli maddi sıkıntı çeken köy kökenli göçmenler toplumsal hayatın dışında kalmayı tercih etmişlerdir. Daha çok kendi aralarında etkileşime giren bu kesim arabeske adeta can simidi gibi sarılmıştır (Işık ve Erol, 2002: 96). Bununla birlikte; Orhan Gencebay "katı kurallara uymaya çalışmayan her şey arabesktir" sözüyle bu türün daha serbest bir yapıda geliştiğini ifade etmektedir. Gencebay'a göre arabesk öğeler ancak özgür bir ortamda 
oluşabilmektedir. Gencebay’ın şarkı sözleri incelendiğinde (Batsın Bu Dünya, Hatasız Kul Olmaz, Dil Yarası) arabeskin özgür ve isyankâr yapısının varlı̆̆ görülmektedir (Meriç, 1994: 32-34). Arabesk müzik türünde acı teması kendini göstermektedir. Orhan Gencebay'ın sözlerinden yola çıkıldığında bu acı insanların tamamen özgürlüğe kavuşmasıyla son bulacaktır.

Kahraman, popüler kültür üzerine yapılan tartışmaları detaylı bir şekilde incelemiş ve çıkarımlara ulaşmıştır. Ona göre popüler kültür sadece bir sonuç olmakla birlikte sosyolojinin içerisinde üremektedir. Yani toplumsal bir olgudur, topluma mal olmuş bir niteliğe sahiptir. Modernleşme ve zamanla kentleşmenin baş göstermesi toplumun ikilemde kalmasına neden olmuş ve zorluklar meydana gelmiştir. Kahraman, arabeskin tam bu noktada geliştiğini ifade etmekte ve halkın yaşadığı zorlukların bir yansıması olduğunu belirtmektedir. $\mathrm{Bu}$ nedenle Türk toplumunda arabesk olgusu yerel bir nitelik arz etmektedir. Irene Markoff, arabesk müzik türünün 1968 yılında Orhan Gencebay ile hayat bulduğunu iddia etmektedir. Markoff o dönem için arabeskin devlet tarafından ikinci plana atıldığını ifade etmiş fakat ilerleyen yıllarda arabeskin her yaştan her kesim tarafından ilgi duyulan bir müzik türü olduğunu sözlerine eklemiştir (Küçükcan, 2011: 38).

Ac1, sefalet ve yoksulluk çerçevesinde ilerleyen arabesk müzik devletin büyük tepkisini çekmiş ve arabesk müziğin engellenmesine yönelik çalışmalar gerçekleştirilmiştir. Bunun neticesinde TRT, 1980'li yılların ilk periyodunda arabesk müziği yasaklamıştır. Ancak bu yasak sadece TRT bünyesinde gerçekleşmiş, arabesk müzik halkın gözünde popülaritesini arttırarak devam ettirmiştir. TRT, acısız olarak tabir edilen arabesk müzik türünü yaygınlaştırmaya çalışsa da halk tarafından hiçbir şekilde ilgi görmemiştir. Özellikle Hakkı Bulut, acısız arabeske yönelik denemeler gerçekleştirmiş, fakat bu tarzın kısa bir süre sonra tutmayacağı anlaşılmıştır (Stokes, 2009:163). Çünkü halk acısız arabesk müzikle özdeşleşememiştir.

\subsection{Türk Sineması'nda Arabeske Giden Yol}

Sinema; toplumsal hayatın ve sorunların yansıtıldığı en önemli kitle iletişim aracıdır. Araştırma, propaganda, eğitim ve öğretim gibi vasıfları da bulunan sinema tüm sanatları bünyesinde barındırmaktadır (Özön, 1985: 12). 7.sanat olarak ifade 
edilen sinemada da toplumsal hayattaki değişim derin bir şekilde hissedilmektedir. Sanatı toplumsal hayattan ayrı bir şekilde değerlendirmek olanaksızdır. Özellikle sinema; yaşadığı toplum düzenini adeta bir ayna gibi yansıtmaktadır. Arabesk kültürün oluşması ve arabesk müziğin yoğun ilgi görmesiyle birlikte Türk Sineması'nda “Arabesk Filmler Dönemi” başlamıştır.

Cumhuriyetin ilk yıllarından itibaren Mısır filmleri halkın büyük bir kesimi tarafından ilgiyle izlenmiştir. Anadolu insanı, Mısır filmlerine ailece gitmeye başlamış ve bu filmlerden etkilenmiştir. Mısır filmlerinde dramatik öğeler ve özellikle de müzik ön plana çıkmıştır. Filmlerdeki göz yaşartıcı öyküler acı ve keder yüklü şarkılarla birleştirilmiştir. Bu filmler arasında "Leyla ve Mecnun”, "Şark Yıldızı”, “Aşkın Gözyaşları” ve “Avare”yi saymak mümkündür (Güngör, 1993: 68). Türk izleyicilerin bu filmlere ve özellikle de filmlerdeki şarkılara yoğun ilgi göstermesi bestecileri ve sinemacıları yeni arayışlara yöneltmiştir.

1950 yılından itibaren Türk Sineması'nda köklü değişimler yaşanmaya başlamıştır. Sinema bu yıllarda siyasal hayattan etkilenmiştir. Türkiye'nin tek partili dönemden çok partili döneme geçtiği bu dönemde sinema ekonomik sarsıntılardan etkilenmiştir. 1960'lı yıllarda ekonomik bakımdan güçlenmeye başlayan Türkiye'de çekilen filmlerin sayısında hızlı bir artış yaşanmıştır. Sinema sanatı en önemli eserlerini bu dönemde vermeye başlamış ve Yeşilçam oluşmuştur. 1968 yılında Türkiye arabeskle tanışmaya başlamış ve Orhan Gencebay "Bir Teselli Ver” adlı 45'lik plağını çıkartmıştır. Bir Teselli Ver ile birlikte Orhan Gencebay'in oluşturmuş olduğu bu tarza arabesk adı verilmiş ve arabesk büyük kentlerin çevresinde yaşayan özellikle gecekondu kesimlerinin ilgi gösterdiği dolmuş, minibüs müziği halini almıştır. Orhan Gencebay’ın bestelemiş olduğu "Batsın Bu Dünya”, "Hatasız Kul Olmaz", "Yarabbim”, "Feryada Gücüm Yok” gibi şarkılar aynı zamanda Türk Sineması'nda da kendisine yer bulmuş ve Yeşilçam'da arabesk furyası başlamıştır.

Arabeskin Orhan Gencebay ile hayat bulduğu y1llarda televizyon yayıncılığında köklü değişimler yaşanmaya başlamıştır. 1968 yılında TRT bünyesinde başlayan televizyon yayınları Türk Sineması'nın olumsuz bir şekilde etkilenmesine neden olmuştur. 1961 Anayasası ile TRT'ye verilen özerk yapı, 1971 muhtırasının ardından yerini tarafsızlığa bırakmıştır. Her gelen iktidar öncelikle 
TRT'nin genel müdürünü değiştirmiş ve sürekli olarak yayınları kontrol etme arzusu içerisinde olmuştur. Arabeskin televizyon yayınlarında yer bulamaması ve sinemanın televizyona oranla daha özgür bir ortam oluşturması arabeskin sinemada hayat bulmasını sağlamıştır. 24 Aralık 1978 yılına kadar bu anlayış değişmemiştir. Fakat TV Dairesi Başkanı Yılmaz Dağdeviren'in yapmış olduğu girişimlerle birlikte Orhan Gencebay ilk defa televizyona çıkarak kendi parçalarını seslendirmiştir. Böylece arabeske yönelik meydana gelen büyük bir tabu yıkılmıştır (Serim, 2007: 101).

Arabesk furyasının başladığı 1960-1970'li yıllarda Türk toplumunda da sosyolojik açıdan önemli değişimler yaşanmaya başlamış, kültürel değerler yeniden oluşum evresine geçmiştir. Sanayileşme, büyük kentlere göç, işçi sınıfının etkisinin hissedilmesi ve kötü hayat standartları bireylerin farklı alternatiflere yönelmesine neden olmuştur. Sendikalaşma, grev hakkı, yaşam koşullarının düzeltilmesine yönelik gerçekleştirilen faaliyetler kültür-sanat alanında yer bulmuş; görsel-işitsel medya da yaşanan bu değişimden önemli ölçüde etkilenmiştir (Kasım ve Atayeter, 2012: 27).

O dönem mutsuzluk ve acıyı aşıladığı düşünülen ve gecekondu kültürü olduğu varsayılan arabeski sadece Orhan Gencebay değil, Emel Sayın ve Zeki Müren de kullanmıştır. Gerek Emel Sayın ve gerekse de Zeki Müren Türk müzik tarihinin en önemli sanatçılarındandır. Ancak bu iki sanatçı da popüler filmlerinde arabesk müzikten yararlanmışlardır. Sayın ile Müren'in tarzında sadece acı, çile, hüzün değil aynı zamanda neşe, zevk, aşk, mutluluk ve sevgiye dair öğeler de bulunmaktadır (Öztürk, 2005: 429). Bununla birlikte arabesk müzik icra eden birçok şarkıcı ve besteci ortaya çıkmış, fakat ses getirememişlerdir.

1970’li yıllarda arabeskin yanı sıra toplumsal gerçekçi filmler de çekilmeye başlamıştır. Yılmaz Güney'in "Umut” isimli filmi ile birlikte toplumsal mesaj kaygısı taşıyan yapıtlar çekilmeye başlamıştır (Esen, 2002: 104). 1970'li yıllarda televizyonun yayın hayatına başlamasıyla birlikte Yeşilçam'a olan ilgi azalmaya başlamış ve izleyiciler tek kanal olan TRT’ye yoğun şekilde ilgi göstermişlerdir. Aynı zamanda siyasal çatışmaların meydana getirdiği gergin hava nedeniyle toplum sinemalara gitmek yerinde evinde televizyon izlemeyi tercih etmiştir (Esen, 2000: 145). Bütün bu olaylar üzerine yıllardır sinemayla uğraşan yapımcı ve yönetmenler 
tabiri caizse izleyiciye küsüp sinema sanatı ile ilgilenmeyi tamamen bırakmışlardır. Sinemayla uğraşmaya yeni yeni başlayan bir kesim ise sinemanın kurtuluşu için çareler aramışlardır. Sinema seyircisinin salonlardan tamamen kopmaması için birçok yol denenmiş, neticesinde yapımcılar fantastik ve özellikle de erotik filmler çekmeye yönelmişlerdir (Scognamillo, 1991: 121).

1970’li yıllar Türk Sineması'nın altın çağları olarak nitelendirilmektedir. Yıllık film üretimi hızlı bir ivme kazanmış ve yılda yaklaşık 300 film üretilmiştir. Hatta dağıtım ağı güçlenmiş ve filmler Anadolu'nun ücra köy ve kasabalarına da ulaşabilmiştir. Ancak bu dönem çok kısa sürmüş ve Türk Sineması kendini çok büyük bir krizin tam ortasında bulmuştur. Toplumsal dönüşümün yaşanması Türk Sineması'nda katı bir sansürün uygulanmasına neden olmuştur. $\mathrm{Bu}$ nedenle yapımcılar, yönetmenler ve senaristler oto sansür uygulamak zorunda kalmışlardır. Yeşilçam'ın en kaliteli filmlerinin üretildiği bu dönemde dişa açılım yeteri kadar sağlanamamış ve çekilen filmler Türkiye sınırlarını aşamamıştır. Bazı Ortadoğu ülkelerine ihraç edilen filmler olsa da yaşanan petrol krizi ve Kıbrıs Savaşı film endüstrisini olumsuz bir şekilde etkilemiş (Söğüt, 2009: 39-40), böylelikle Türk Sineması zor bir periyodun içerisine girmeye başlamıştır.

\subsection{Arabesk Film Furyası ve Filmlerin Yapısı}

Arabesk film furyası Türk Sineması'nın belirli bir dönemine damgasını vurmuş ve izleyiciler çekilen filmlere yoğun ilgi göstermişlerdir. $\mathrm{Bu}$ ilginin altında yatan en önemli etkenler ise Türk toplumunun sosyo-ekonomik ve sosyo-kültürel yapısıdır. Filmlerin başrol oyuncularıyla özdeşleşme ve onlarla aynı sorunları yaşama özellikle köyden kente göç eden kitlenin arabesk filmlere olan ilgisini arttırmıştır. Bu nedenle arabesk filmleri dönemlere göre incelemek yerinde olacaktır.

\subsubsection{0'li Yıllar}

1970'li yıllarda fantastik ve erotik filmlerin çekilmeye başlamasıyla birlikte Türk Sineması geçici bir süre için de olsa nefes almaya başlamış, bununla birlikte müzik alanında yaşanan hareketlenmeye duyarsız kalamamıştır. Yeşilçam gecekondularda yaşayan insanların benimsediği arabesk müzikten yararlanmayı bilmiştir. 1970'lerin sonlarına doğru Orhan Gencebay ve Ferdi Tayfur'un filmleriyle 
başlayan arabesk furyası 1980'lere gelindiğinde farklı bir boyut kazanmıştır. 1979 yılında Türk Sineması'nda çekilen 195 filme bakıldığı vakit bunlardan sadece 19 'unun (\% 9,7) arabesk temelli olduğu görülmektedir (Esen, 2000: 146). Ancak; çekilen bu filmler 80’lerde yaygınlaşacak arabesk temelli filmlere örnek teşkil etmiştir.

1970’li yıllarda gelişim gösteren arabesk müzik, Türk Sineması'nda da kendisini göstermeye başlamış, böylece yapımcılar arabeskçilerin başrolde yer aldığı filmlere yönelmiştir. Arabesk müzik, Türk Sineması'nın biçimsel ve içeriksel açıdan değişmesine neden olmuş ve toplumun sorunları sinemada yer bulmuştur. 1970'li yılların son dönemleri toplumsal hayat açısından zorluklarla geçmiştir. 70'lerin sonlarında yaşanan terör olayları, sağ-sol çatışmaları, kardeşlerin birbirlerini hiç acımadan öldürmesi değişen toplum yapısını tamamen yozlaştırmıştır. Toplumsal hayattan sinemanın etkilenmesi olanaksızdır. Artan terör olayları sinemayı durma noktasına getirmiş ve izleyici sinema salonlarından kopmuştur (Scognamillo, 1991: 122).

\subsubsection{0 'li Yillar}

1980 yılından itibaren arabesk filmlerde büyük bir patlama yaşanmıştır. Bu patlamanın meydana gelmesine 12 Eylül 1980 tarihindeki askeri darbenin etkisi büyüktür. Askeri darbe ile birlikte toplumsal dinamikleri köklü bir değişime uğramıştır. Toplumsal koşulların değişmesi, sinema sanatına da etki etmiştir. O güne değin sinemada kurtarıcı olarak görülen şiddet ve erotizm içerikli filmler yasaklanmıştır. Bu filmlerin seyirci kitlesinin kaybolması yapımcıları çeşitli yollara sevk etmiştir. Askeri darbenin ardından sıkıyönetim dönemi başlamış ve toplumsal eleştiri yapan filmler de tamamen yasaklanmıştır. Böylelikle; başta arabesk içerikli filmler olmak üzere, bireysel bunalımlar ve kadın sorunları Türk Sineması'nda yer bulmuştur (Esen, 2002: 104).

1980-1990’11 yıllar arabeskin çehresinin değişime uğradığı bir dönem olarak ön plana çıkmaktadır. Bu dönem arabesk müzik dinleyici kitlesini genişletmiş, böylelikle toplumun farklı kesimleri bu türle tanışmıştır. Arabeskin gelişim göstermesinin temelinde siyasal hayatta yaşanan değişimler yatmaktadır. 1983 
yılında Turgut Özal'ın kurmuş olduğu Anavatan Partisi'nin iktidara gelmesiyle birlikte TRT'nin yasakladığı arabesk müzik tekrardan radyo ve televizyonda kendisine yer bulmaya başlamıştır. Özellikle bu yıllar içerisinde arabesk müzikle uğraşan sanatçılar TRT ekranlarında seyircilerle buluşmuştur. Arabeskin televizyonda kendisine yer bulması ile birlikte arabesk müzik toplumun geniş bir kesimi tarafından tanınmış ve ön yargılar kırılmaya başlamıştır (Küçükkaplan, 2012: 161).

Gecekondulaşma ile birlikte ivme kazanan arabesk, giderek egemen kültüre dönüşmeye başlamıştır. "Minibüsçülük" ve "gecekondulaşma" bu filmlerin merkezinde yer almıştır. Filmlerde ana kahraman genellikle gecekondu mahallesinde yaşamaktadır. Bunun yanında zengin kız - fakir erkek teması arabesk filmlerin çoğunda kendisini göstermektedir. Başrollerini İbrahim Tatlıses ve Hülya Avşar'ın paylaştığı 1985 yapımı Mavi Mavi isimli film de bu tema üzerine kuruludur. Gecekondularda ortaya çıkan ve şehirlere yayılan arabesk müzik toplumsal hayatın merkezinde yer almaya başlamıştır. İsyankâr ve çığırtkan bir üsluba sahip olan arabesk kimi zaman nefret dolu duyguları da empoze edebilmektedir (Öztürk, 2004: 14-15).

1981 yilından çekilen 72 filmin 33 tanesi (\% 45,8) arabesk kategorisinde yer almaktadır (Esen, 2000: 146). Bu döneme Orhan Gencebay'ın, Ferdi Tayfur'un, Müslüm Gürses'in, İbrahim Tatlıses'in ve Gökhan Güney'in filmleri damga vurmuştur. Bu tip filmlerin konuları birbirine çok benzemektedir. Filmlerde acı teması derin bir şekilde hissedilmektedir. Fakat bu acı eski Yeşilçam melodramlarından farklıdır. Bu acının ortaya çıkışını hüzün, karasevda, çile, hor görülme, dışlanma, kahrolma, yoksulluk, kötü yazgı, yakınma, umutsuzluk, karamsarlık, kadercilik ve kan davası gibi olgular oluşturmaktadır. Arabesk filmlerde mutluluk ve sevince kısa sürelidir, yani aldatmacadır (Evren, 1997: 116).

Arabesk filmfuryasında konudan ziyade söylenen şarkılar büyük önem arz etmektedir. Filmlerin hemen hemen hepsinde arabeskçiler çıkarmış oldukları plaklardaki/kasetlerdeki şarkıları seslendirmekte ve bu sahneler adeta bir video klip tarzında çekilmektedir. Filmlerde yer alan sahnelerin genel özellikleri ise şu şekildedir (Erşanlı: 2012: 121): 
- $\quad$ Sahnelerde şarkıların sözleri ön plana çıkmaktadır.

- $\quad$ Sahnelerde, gösterişten uzak görsel unsurlar yer almaktadır.

- $\quad$ Sahnelerde sözler ön plana çıkabilmekte ve gösterişten uzak görsel unsurlara eş zamanlı bir şekilde başvurulabilmektedir.

Soyut görüntüler ve hayallerle kurulu bir içeriğe sahip olabilmektedirler.

Genelde birçok film zengin kız ile fakir erkek arasındaki aşk üzerine kurulmuştur. Fakat bu aşk olanaksız veya platoniktir. Fakir erkek rollerinde arabesk türünde şarkı söyleyen müzisyenler görülmektedir. Filmlerdeki zengin kız rolünde ise genellikle Necla Nazır, Perihan Savaş, Oya Aydoğan, Serpil Çakmaklı görülmektedir. Olanaksız aşk ve olanaksız sevgi kahramanların tüm hayatını etkilemektedir. Filmlerdeki kızların babası çoğunlukla ağadır. Ağa; taş kalpli ve hak yiyicidir. Gözünde kestirdiği zengin damat adayıyla kızını evlendirmek istemektedir. $\mathrm{Bu}$ açıdan filmlerdeki erkek karakter olan arabesk müzik şarkıcıları köyden kente göç etme ve zengin olma amacını taşımaktadırlar. İçlerinde hep ağadan intikam alma arzusu yatmaktadır. Gecekondularda yaşayanlar da köyden kente göç ettikleri için filmlerdeki ana karakterle özdeşleşmekte ve kendilerini onun yerine koymaktadırlar. Dürüst delikanlı kente gelmekte ve gazinolarda müzik dünyasının aranan bir şarkıcısı olmaktadır. Para ve şöhret sahibi olan genç köye geri dönerek sevdiği kıza kavuşmak istemektedir. Ancak filmin sonunda sevenler birbirine kavuşamamaktadır (Evren, 1997: 117). İzleyiciler bu filmleri izleyerek rahatlamış ve umutlarını canlı tutmuşlardır. Mutlu olabilme ümidi filmler aracılığıyla izleyicilere yansıtılmaktadır.

Arabesk film furyasında melodram anlayışı hâkim bir durumdadır. Filmin başrol oyuncuları çoğu zaman kırdan kente göç etmiş, ekonomik açıdan hiçbir imkânı olmayan, köy-kent ikileminde kalmış fakir ama onurlu gençlerdir. Arabesk film furyasının o dönemki koşulları göz önüne alındığında "kadercilik" yaklaşımının köyden kente göç eden bireyler için uygun olduğu açık bir şekilde görülmektedir. Fakat kötü yola düşen kadınlar, namus cinayetleri, sonu olmayan aşklar, mahkum 
olma, suç işleme bu türün spesifik özellikleri arasında yer almaktadır (Önk, 2011: 3872). Müzik hemen hemen her sahnede izleyicinin karşısına çıkmakta ve derin bir etkileme gücü oluşturmaktadır. Filmlerdeki mutsuzluğa ve acıya rağmen izleyiciler hikâyede kendilerinden bir şeyler bulmakta ve acı çeken başrol oyuncusuyla ister istemez özdeşleşmektedir.

Mutsuzluk ve acıyla örülmüş bir yapıya sahip olan arabesk filmlerde İstanbul'un bütünlüğünü görebilmek neredeyse imkânsızdır. Mekân olgusu sürekli değişmektedir. Kır ve kent arasında mekik dokuyan ana karakterin hayatı iki alanda geçmektedir. Filmlerde ata-erkillik olgusu sıkça karşılaşılan bir durumdur.. Zengin ve fakir gencin aşkını sadece arabesk filmlerde değil; arabesk filmlerden önceki Yeşilçam melodramlarında da görmek mümkündür. Bu açıdan arabesk filmler Türk Sineması'nda popüler bir hale gelmiş ve geniş kitleler tarafından izlenmiştir (Öztürk, 2005: 432).

Arabesk filmlerde "öteki" kavramı merkezde yer almaktadır. Ailelerin yıkımı, şehre yabancı kalma, iş-kumar ikilemi gibi temalar filmlerin birçoğunda görülmektedir. Senaryolarda ise çelişen öğeler bulunmakla birlikte seyirci var olan durumu kendine özgü yöntemlerle analiz edebilmektedir. Dramatik olay örgüsü sürekli müzikle desteklenmekte ve filmlerin adı genelde şarkıcıların söylediği parçalar olmaktadır. Filmin başrol oyuncuları sıkıntıların baş gösterdiği ortamlarda acılarını, bahtsızlıklarını, sorunlarını söylediği hüzünlü şarkılarla dışa vurmaktadır. Filmlerin olay örgüleri arabesk şarkılarla desteklenmekte ve dış müzikler genelde batı kaynaklı olmaktadır. Oyuncular filmlerde ortalama üç-dört parça seslendirmektedir. Dinleyiciler tarafından en beğenilen parçalar filmin en dramatik anında çalınmaktadır (Stokes, 2009: 202). Böylece duygu yoğunluğu yaşanmakta ve coşkular doruk noktasına ulaşmaktadır.

Arabesk dünyasına Orhan Gencebay, Ferdi Tayfur, Müslüm Gürses ve İbrahim Tatlıses'ten sonra çocuk yıldızlar da adım atmaya başlamıştır. 80'li yılların ikinci yarısında yaşı 12- 16 arasında değişen küçük arabeskçiler ortaya çıkmıştır. Acı dolu sözleri çocukların söylemesi çok daha etkili olmuş ve kitleler etkilenmiştir. Çocuk arabeskçilerin en bilinenleri Küçük Emrah ve Küçük Ceylan’dır. Bu iki isim günümüzde de müzik yaşantılarına devam etmektedir. Daha sonra bu isimler de 
arabesk film furyasına dahil olmuş ve bu türde filmler çekmişlerdir. Emrah'ın oynamış olduğu “Acıların Çocuğu” filmi yediden yetmişe tüm Türk halkını derinden etkilemiştir. Filmlerinde Emrah ve Ceylan ya öksüz ya da yetimdir. Çocuk arabeskçiler de filmlerinde fakirdirler. Ancak her şeye rağmen hayattan soğumamışlardır (Güngör, 1993: 68). Prodüktörler onlara hem albümler yapmış hem de birçok filmde oynatmışlardır. Fakat bu çocuklar daha sonra psikolojik bakımdan çökmüş ve davranış bozuklukları göstermişlerdir.

Arabesk furyası sinema salonlarında varlığını sürdürürken video film teknolojisi Türkiye'de yaygınlaşmaya başlamıştır. Video oynatıcıların yaygınlaşması ile birlikte çeşitli Türk filmleri telesine cihazı aracılığıyla videobantlara aktarılmıştır. $\mathrm{Bu}$ şekilde yeni bir ticari alan doğmuştur. Ancak video teknolojisi sinemanın bir sanat olarak gelişmesini olumsuz yönde etkilemiştir (Scognamillo, 1996: 94). Video filmler çok düşük maliyetlerle, yoğun çaba sarf edilmeden çekilmiş ve arabesk dünyasının önde gelen sanatçıları zamanla video film sanayinin vazgeçilmezi durumuna gelmişlerdir. Bu filmlerin senaryo yapısı basit bir o kadar da birbirine benzerdir. 1990'l1 yıllara gelinene dek arabesk filmler gerek videokasetlerde gerekse de sinema salonlarında halk tarafından ilgiyle izlenmiştir. Filmlerin çekimleri çok kısa sürede tamamlanmıştır. Yönetmenliğini Ertem Eğilmez’in yaptığı 1988 yapımı "Arabesk” filmi o dönemde var olan arabesk furyasını hicvetmiştir. 1990 yılında ise Türkiye'de büyük bir ekonomik kriz meydana gelmiş ve sinema sektörü bu krizden yoğun bir şekilde etkilenmiştir.

\subsubsection{0'lı Yıllar}

1990’l1 yıllarda çekilen arabesk filmler birbirini tekrar eder nitelikte olup, özgün konulara sahip değillerdir. Abisel (2005: 121) izleyicilerin kısa süre içerisinde çekimleri tamamlanan video filmlere ilgi göstermediğini ifade etmektedir. O dönemde çekilen filmlerin birçoğunun senaryosunun benzer nitelikte olduğunu belirten Abisel, ekonomik krizin yanında filmlerin kalitesiz oluşunun da arabesk furyasının noktalanmasından önemli bir paya sahip olduğunu ifade etmiştir. Toplumsal değişim ve özel televizyon kanallarının yayın hayatına başlaması üzerine arabesk filmler dönemi tamamen sona ermiştir. 


\section{Sonuç}

Kitle iletişim araçları içerisinde sinema ayrı bir öneme sahiptir. Bir sanat ve öykü anlatma aracı olan sinema görsel ve işitsel yönü nedeniyle içinde yaşanılan gerçekliğe ayna tutmaktadır. Her yaştan ve her gruptan izleyiciye ulaşabilen sinema kimi zaman da toplumsal yapıyı değiştirebilecek işlevler üstlenebilmektedir. Zaman ve mekân kavramının farklı bir boyut kazandığı sinema sanatı ülkeden ülkeye, hatta yönetmenden yönetmene değişiklik göstermektedir.

1950 y1lından itibaren Türkiye'nin toplumsal hayatında köklü değisşimler yaşanmaya başlamıştır. Sanayi devrimi ile birlikte büyük kentlerdeki hayat standartları gittikçe yükselmiş ve endüstri alanında önemli gelişmeler kat edilmiştir. Ancak, Türkiye'de köyden kente göç; sanayileşmeyi aşan bir hızla gerçekleşmiş ve kırsal kesimlerde yaşayan insanlar büyük kentlere yönelmiştir. Bu nedenle kentlerde düzenli istihdam ve iskân sağlanamamış ve gecekondulaşma meydana gelmiştir. Kent merkezlerinde ev bulamayan ya da evlerinin kiralarını ödeyemeyen göçmen kesim şehir merkezlerinin dışındaki gecekondulara yerleşmiş ve buralarda gecekondu mahalleleri oluşturmuşlardır.

1960’lı yıllar siyasetin yanında müzik alanında da büyük değişimlere sahne olmuştur. Türkiye'de Orhan Gencebay o ana kadar yapılmamış özgün bir müzik türünü ortaya çıkarmış ve bu türe "arabesk" adı verilmiştir. Arabesk tarzının oluşmasında 1930'larda Türkiye'de gösterime giren Misır filmlerinin etkisi çok büyüktür. Arabesk; Türk sanat müziği ve Türk halk müziğinin sentezinden oluşmakla birlikte acı ve keder bu türün temel dayanak noktasında yer almaktadır. Akrabaları ve sevdikleri köylerde kalmış göçmen kesim kentte zor hayat koşullarıyla baş başa kalmış, kente alışamamış ve yabancılaşmıştır. Arabesk müzikle gecekondu kesimi adeta bütünleşmiş ve katharsis meydana gelmiştir. Orhan Gencebay’ın ardından Ferdi Tayfur, İbrahim Tatlıses ve Müslüm Gürses müzik dünyasında ön plana çıkmaya başlamıştır.

1970'li yıllarda televizyonun yaygınlaşma başlamasıyla birlikte sinema etkisini yitirmeye başlamış; yapımcılar fantastik ve erotik içerikli filmlere yönelmişlerdir. Özellikle Orhan Gencebay'ın filmleri ile birlikte o dönem sadece 
gecekondularda dinlenen ve "minibüs müziği”" olarak nitelendirilen arabesk şarkılar orta kültür düzeyine ait kesim tarafından da dinlenir duruma gelmiştir. 1980 yılından itibaren siyasal dönüşümün etkisiyle birlikte erotik filmler yerini tamamen arabeske bırakmıştır. Arabesk filmlerin kahramanlarıyla kendini özdeşleştiren genç kuşak böylelikle toplumda alışılagelen kültür anlayışının değişmesini de sağlamıştır. Başlangıçta küçümsenen ve alt sınıfa ait olarak görülen arabesk, 80’lerin ortalarında her yaştan her kesime ulaşmaya başlamıştır.

Arabesk içerikli filmler toplumsal yapıda meydana gelen değişikliği beyazperdeye aktarmış ve birçok müzisyen zamanla bu alana yönelmiştir. $\mathrm{Bu}$ dönüşümün temelini popüler kültürün toplum içerisinde yaygınlaşması oluşturmuştur. Çünkü çekilen bu filmler "afyon etkisi” yaratmış ve bireyler gündelik yaşamın vermiş olduğu sıkıntı ve sorunlardan bir nebze de olsa uzaklaşabilmişlerdir. Gerek sinema salonlarında gerekse de videolar aracılığılla evlerde arabesk filmler yoğun ilgiyle izlenmiştir. Bunun üzerine yapımcılar çocuk arabeskçileri müzik piyasasına çıkarmışlardır. Küçük Emrah ve Küçük Ceylan üzerinden para kazanan yapımcılar onların başrolde oynadığı filmlerde acı, hüzün keder ve ayrılık temalarını işlemişlerdir.

Arabesk furyası 1980'lerin sonlarına doğru popülaritesini yitirmeye başlamış ve 1988 yapımı Ertem Eğilmez imzalı “Arabesk” filmi ile bu dönem hicvedilmiştir. Konusunu arabesk tarzındaki yapımların karışımından alan filmde zengin kız ile dürüst fakir erkeğin aşkı konu edilmektedir. Arabesk furyasındaki acı öğesi bu filmde yerini komediye bırakmıştır. Film; halkın tüm kesimi tarafından beğeniyle izlenmiştir. Arabesk filminin ardından bu furyanın da sonu gelmiştir. Arabesk furyasının noktalanmasında gecekondu kesiminin sosyal bakımdan sınıf atlamasının rolü büyüktür. Kırdan kente göç eden kesimin gelirini arttırması ve kent merkezlerine yerleşmesi de arabesk furyasının bitmesine neden olan bir diğer özelliktir.

Görüldüğ̈̈ gibi arabesk Türk Sineması'nın bir dönemine damgasını vurmuş ve izleyici bu filmlerde adeta kendisini bulmuştur. Filmlerde popüler kültür alt metinlerle izleyicilere aşılanmıştır. Popüler kültür; içinde yaşanılan toplumsal gerçekliği değiştirip yeni bir hayat kurma isteğini canlı tutmuş ve topluma umut 
aşılamıştır. Bu sayede bireyler düşlerini, tasarılarını canlı tutabilmiş ve ümitlerini yitirmemişlerdir. Arabesk filmlerde popüler kültürün sunduğu umut öğesini her zaman görebilmek mümkündür. Dürüst delikanlı fakir de olsa sevdiği zengin kıza kavuşma umudunu her zaman taşımaktadır. Yine dürüst delikanlı er ya da geç zengin olup düşmanlarından intikam almayı amaçlamaktadır. Her dönem kendi koşulları göz önüne alarak değerlendirilmelidir. Türkiye'nin o dönemki koşulları irdelendiği vakit arabesk filmlerin kendine has seyirci kitlesini oluşturduğu ve amacına ulaştığı açıkça görülmektedir.

\section{KAYNAKÇA}

ABİSEL, Nilgün (2005). Türk Sineması Üzerine Yazılar, Ankara: Phoenix Yayınevi. ALEMDAR, Korkmaz ve ERDOĞAN, İrfan (1994). Popüler Kültür ve İletişim, Ankara: Ümit Yayınları.

ANA BRİTANNICA (1992). Cilt: 2, İstanbul: Hürriyet Gazetesi Yayınları.

ANGI, Çiğdem Eda (2013). “Müzik Kavramı Ve Türkiye'de Dinlenen Bazı Müzik Türleri”, İdil Sanat ve Dil Dergisi, Cilt:2, Sayı: 10.

BAĞLI, Mazhar (2004). "Batman İntiharları Bağlamında Özgürlüğün ve Geleneksel Toplumsal Yapının Kentsel Kurgusu”, Kriz Dergisi, No:12. 1.

BATMAZ, Veysel (1981). "Popüler Kültür Üzerine Değişik Kuramsal Yaklaşımlar”, Ankara İletişim Dergisi, Sayı: 1.

BELGE, Murat (1983). Tarihten Güncelliğe, İstanbul: Alan Yayınları.

BİRKALAN, Hande (2003). Arabesk'te Politika ve Poetika, Folklor / Edebiyat Dergisi, Cilt: 4, Sayı: 36

BÜYÜK LAROUSSE (1986). Cilt: 2, İstanbul: Milliyet Gazetesi Yayınları.

COŞKUN, Ahmet Hakan (2001). Orhan Gencebay - Ne Olur Sev Beni, İstanbul: Birey Yayınc1lık.

ÇALIŞKAN, Zekeriya (2006). "Türkiye'de Şehirleşme ve Gecekondulaşma”, Frrat Üniversitesi Doğu Anadolu Bölgesi Araştırmaları Dergisi. 
DÖNMEZ, Banu Mestan (2011). "Katharsis Fenomeninin Arabesk Özelindeki Görünümü”, Uluslararası İnsan Bilimleri Dergisi, Cilt: 8, Say1: 2.

ERŞANLI, Banu (2012). "Bir Alt Kültür Yansıması Olarak Arabesk Video Müzik Klipleri Dilinin İncelenmesi”, Batman University Journal Of Life Sciences, Cilt: 1, Sayı: 1.

ESEN, Şükran (2000). 80’ler Türkiyesi'nde Sinema, İstanbul: Beta Yayınları.

ESEN, Şükran Kuyucak (2002). Türk Sinemasının Kilometre Taşları, İstanbul: Naos Yayınları.

EVREN, Burçak (1997). Değişimin Dönemecinde Türk Sineması, İstanbul: Leya Yayınc1lık.

GÜLLÜPUNAR, Hasan (2013). “Belediye Başkanlığı Aday İmajı Algısı: Gümüşhane Örneği”, İletişim Kuram ve Araştırma Dergisi, Sayı:36.

GÜNGÖR, Nazife (1993). Arabesk: Sosyokültürel Açıdan Arabesk Müzik, Ankara: Bilgi Yayınevi.

GÜRBİLEK, Nurdan (2009). Vitrinde Yaşamak, İstanbul: Metis Yayıncılık.

IŞIK, Caner ve EROL, Nuran (2002). Arabeskin Anlam Dünyası, İstanbul: Bağlam Yayınları.

KASIM, Metin ve ATAYETER, H. Deniz. (2012). “1960’lı Y1llarda Türk Sinemasında Toplumsal Gerçekçilik”, Gümüşhane Üniversitesi İletişim Fakültesi Elektronik Dergisi, Sayı: 4.

KIRAY, Mübeccel B. (2007). Kentleşme Yazıları, İstanbul: Bağlam Yayınları.

KÜÇÜKCAN, Talip (2011). Toplumun, Kültür Politikaları Ve Medyanın Kültürel Süreçlere Etki Algısı Araştırması, Ankara: SETA

KÜÇÜKKAPLAN, Uğur (2012). 1930'lardan Bugüne Türkiye'de Arabesk Müziğin Kültürel Zemini ve Toplumsal Müzikal Analizi, İstanbul: Mimar Sinan Güzel Sanatlar Üniversitesi Sosyal Bilimler Enstitüsü, Basılmamış Yüksek Lisans Tezi. 
KONGAR, Emre (2004). 21. Yüzyılda Türkiye: 2000'li Yıllarda Türkiye'nin Toplumsal Yapısı, İstanbul: Remzi Kitabevi.

MERİÇ, Ümit (1994). Sosyoloji Konuşmaları 1993-1994, İstanbul: Genç Sosyologlar Derneği Yayınları.

MEYDAN LAROUSSE (1992). Cilt:2, İstanbul: Sabah Gazetesi Yayınları.

MONACO, James (2006). Bir Film Nasıl Okunur ? - Sinema Dili, Tarihi ve Kuramı, İstanbul: Oğlak Yayıncılık.

OKTAY, Ahmet (1987). Toplumsal Değişme ve Basın, İstanbul: Bilim-Sanat-Felsefe Yayınları.

OSKAY, Ünsal (1995). Müzik ve Yabancılaşma, İstanbul: Der Yayınları.

ÖNK, Ürün Yıldıran (2011). “Türk Sineması'nda Türler Üzerine Bir İnceleme (1970-1980), Journal Of Yasar University, Cilt: 23, Say1: 6.

ÖZBEK, Meral (2008). Popüler Kültür ve Orhan Gencebay Arabeski, İstanbul: İletişim Yayınları.

ÖZÖN, Nijat (1985). Sinema Uygulayımı-Sanat1-Tarihi, İstanbul: Hil Yayınları.

ÖZTÜRK, Mehmet (2004). “Türk Sinemasında Gece Kondular”, European Journal of Turkish Studies, Sayı: 1.

ÖZTÜRK, Mehmet (2005). Sine-Masal Kentler, İstanbul: Don Kişot Yayınları.

SAĞLAM, Serdar (2006). "Türkiye'de İç Göç Olgusu ve Kentleşme”, Hacettepe Üniversitesi Türkiyat Araştırmaları Enstitüsü Dergisi, Sayı: 5.

SCOGNAMİLLO, Giovanni (1991). Cadde-i Kebir'de Sinema, İstanbul: Metis Yayınları.

SCOGNAMİLLO, Giovanni (1996). Yeşilçam'dan Önce Yeşilçam'dan Sonra, İstanbul: Leya Yayıncılık.

SERIM, Ömer (2007). Türk Televizyon Tarihi 1952-2006, İstanbul: Epsilon Yayınevi. 
SÖĞÜT, Fatih (2009). Melodram Türünün Kaynağı Olarak Arabesk Filmler, Kayseri: Erciyes Üniversitesi Sosyal Bilimler Enstitüsü, Basılmamış Yüksek Lisans Tezi.

STOKES, Martin (2009). Türkiye'de Arabesk Olayı, İstanbul: İletişim Yayınları. 